\title{
Women, land, labour and survival: getting some basic facts straight
}

\author{
Caroline Allison
}

It is the African farmer and her husband who plays the main role in African agriculture - A. R. Jolly, UNICEF, 1985 UN Conference on Famine in Africa.

The trend rate of growth in food production in a majority of sub-Saharan African economies has been at levels two thirds or less of population growth over the 1970s, a record significantly worse than for other parts of the developing world [Daniel 1982:25]. The gravity of the current food crisis is graphically illustrated by emaciated and starving bodies flocking to emergency relief centres in the Sahel, Ethiopia and most recently the Sudan. Many are those of women and children, who comprise by far the highest proportion of the resident agricultural work force compared to other regions.

Concern within the international community as to underlying causes and means of forestalling repeated horrors has assumed popular as well as policy and research dimensions. In this context the need to unmask the identities of rural producers and the social dynamics of the rural economy is reinforced, not least to challenge fatalism bred by notions of omnipotent and uncontrollable natural forces.

Questions as to how crises witnessed in the past few years can be prevented from recurring with ever greater frequency and ferocity demand deeper and more coherent understanding of who does what in the rural sector and why their ability to meet the subsistence needs of households or generate marketable surplus sufficient to meet basic needs has in many cases been brought into jeopardy. On this basis alone is it feasible to assess what major types of support rural dwellers require to strengthen and consolidate the survival strategies they have evolved and reverse present, pessimistic trends.

To move one step further towards this goal some basic facts need to be straightened out from a gender perspective - a perspective not blind to broader economic and political mechanisms, but one which will enable us to remove some of the mystique surrounding women's invisibility and the inequalities colouring their interactions and relations with men. This article does not aim to be comprehensive in its coverage of the many issues involved, but concentrates on the questions of land access; household composition; and the survival strategies women rely on in periods of imminent or perceived crisis.

\section{The Need for More Contextural and Specific Analysis}

The starting points for developing analysis of gender relations in the rural sector from the perspective of food crisis are:

First, recognition of the fact that although SSA economies have suffered particularly acutely from the worst effects of recession, most notably since 1981 [UNICEF 1984:139] the impact has not been evenly distributed either within or between countries comprising the region.

Second, to distinguish the impact of recession from on the one hand, seasonal, ecological, climatic factors and on the other, from the specific policies governments have adopted with a view to effecting stabilisation and adjustment. The latter have been particularly significant in determining the way in which the negative effects of economic contraction have been spread among social groups.

Third, to increase analytical precision and policy relevance by situating gender relations firmly in the context of the socioeconomic and political diversity characteristic of the region. This is not to deny the utility of generalisation in highlighting key issues and awareness of them, but to reassert the need for country specific micro analysis rooted in history. Such a framework hinges on recognition of historical and

IDS Bullein. 1985. vol 16 no 3. Institute of Development Studies. Sussex 
contemporary diversity from the perspective of the nature and organisation of production within different communities and between social groups, with a view to evaluating the precise and particular ways in which women have been threatened as food producers, food gatherers, food-makers and food distributors by wider economic and social forces [Ahoja-Patel 1982:22].

\section{Some Factors for Consideration}

\section{Access to Land}

A significant constraint to productivity is lack of access to sufficient land or land of a suitable quality for producing foodcrops or grazing livestock. In analysing the relative significance of this factor for women in various contexts, however, it is important to stress the wide number of uses to which land has traditionally been put and vast differences in patterns of land distribution. To do this, four interrelated dimensions need to be drawn out. First, the system of economic production characteristic of a given community which determines both land use and land requirements (e.g. land suitable for the production of foodcrops or for grazing livestock). Second, patterns of land ownership and distribution within such a community (e.g. private registration, communal ownership, private land tenure, sharecropping). Third, the way in which different types of economic production (e.g. shifting cultivation, nomadic pastoralism, irrigated production schemes, plantation production) are linked and interact at the level of the national economy. Fourth, the size, structure and distribution of a nation's population between different production forms.

Much has been said about the imminent dangers of the 'population explosion' [World Bank 1981] or 'neoMathusian crunch' [Lipton 1984:4] confronting SSA economies, but the mechanisms behind land scarcity where it exists have rarely been subjected to rigorous scrutiny. The recent growth in rural landlessness and forced movement of households onto ecologically marginal land areas has been documented, as has the fact that these groups comprise large numbers of women [World Bank 1981], but are most often attributed to population pressure, over-intensive use or misuse of land rather than, for example, cash cropping, large-scale land appropriation and repeated climatic disasters.

Traditionally, women's access to land irrespective of patterns of land use and distribution was largely contingent on the kinship system. In sedentary agricultural communities, for example, unmarried women would be provided plots of land to farm in the event that they remained single. Married women were allocated independent plots from which they reaped the fruits of their labour in addition to providing labour without reward on plots belonging to their husbands. On divorce or widowhood women and their children would be inherited by male relatives of their husbands or return to their own families. In nomadic pastoralist or hunting and gathering societies, on the other hand, land was collectively used for the purposes of grazing or hunting, but women's economic security hinged on similar kinship structures.

A primary mechanism behind the growth in landless female heads of households, and concentration of these units in least productive land spaces, has been increased privatisation of land linked to disintegration of the extended family system, irrespective of whether these processes have occurred in the context of increased rural inequality or through the introduction of state policy (e.g. resettlement schemes, irrigation projects and land registration) predicted and planned on the basis of male household heads and nuclear units. State policy, privatisation, the rise in individualism and increased impoverishment have all reinforced the tendency towards smaller, less extended household units at the cost of reduced diversification of production within the household and diminished sources of farm and non-farm income. In many cases this process has assumed relatively permanent forms, in others the splintering of larger units during periods of food scarcity and regrouping in more abundant months occurs on a seasonal economic basis [Swift et al 1984].

In cases where women have retained independent rights to cultivable land they are often able to produce significant grain surpluses in addition to vegetables and pulses. The significance of this for food supplies, household income and nutritional standards is, however, ignored in many irrigation and resettlement schemes under which households are allocated 'garden plots', the labour to work which is predominantly that of women and children, although this land is most often registered in the name of male household heads [Fortman 1981:206]. In certain instances women have not been permitted to apply for resettlement independently of a male household head, with the exception of widows who have been allocated half a typical plot [Jacobs 1983:41]. In many, young households on a nuclear model are typically selected as the target group. Women are not only alienated at the planning/implementation stages and deprived access to inputs and information [Weekes-Vagliani 1984:5], but are uprooted from the extended system of solidarity and mutual self-help, thereby encouraging the procreation of large families, because this provides a perceived avenue of future security and support in labour and financial terms. 


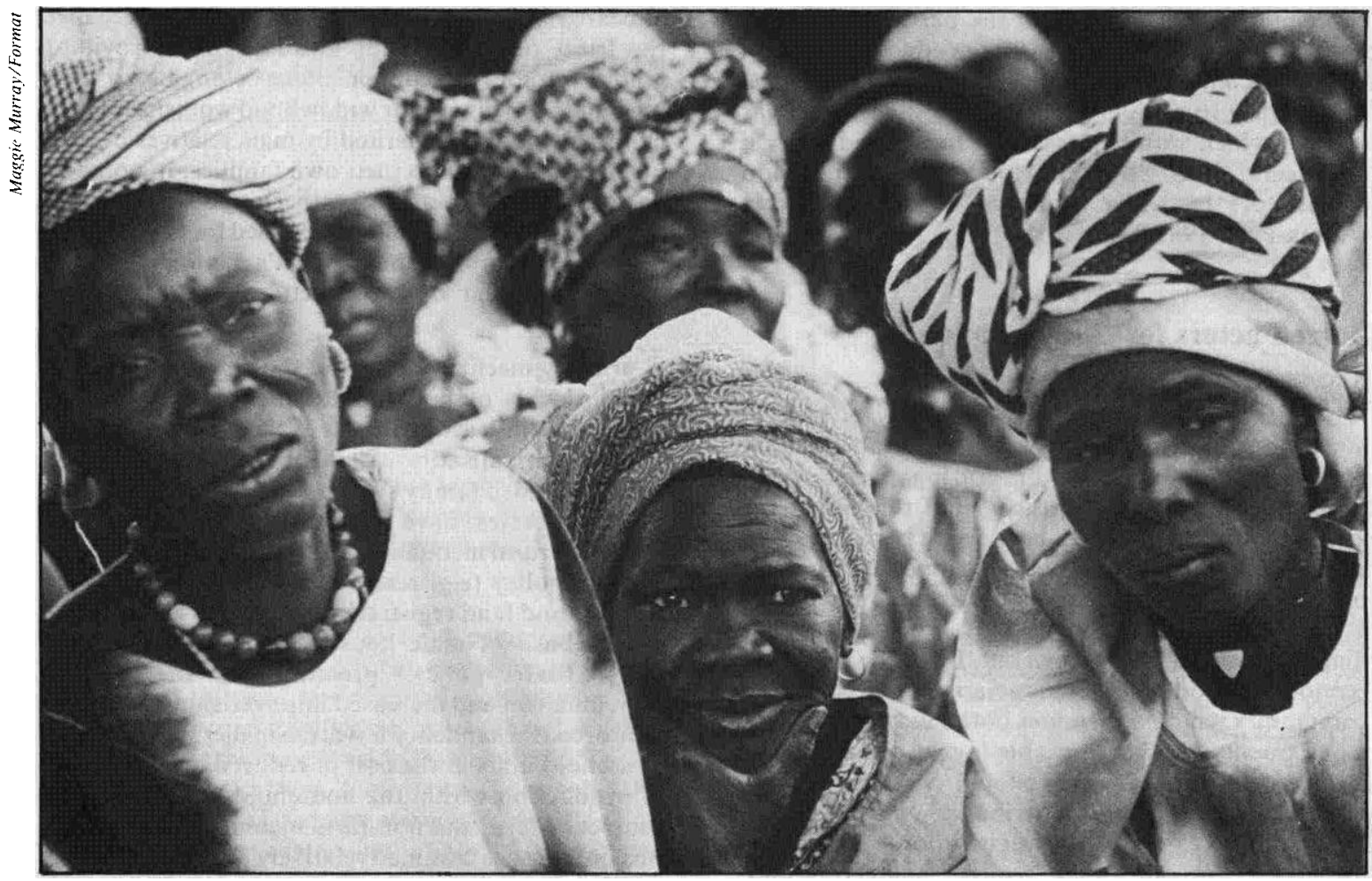

Collective organisation compensates for social dislocation.

Irrigation projects reveal similar problems. Women in the irrigated Damga zone of Senegal, for example, are not allocated plots, irrespective of their marital status [Savane 1985:4]. In Bongoukoire women were exhorted to assist husbands in irrigated rice cropping in view of their expertise in this sphere, but were forced to farm their own rainfed plots for an independent source of income [Bisilliat 1985:4].

\section{Household Composition, Patterns of Labour Use and the Gender Division of Labour}

The task of challenging stereotypes of household units derived from Eurocentric conceptions of a male household head with dependent wife and children has proved an uphill struggle at the level of research, and often a lost battle at the level of policy. Analytically there is increasing recognition of, for example, the need to take into account polygamous household forms and extended family structures in African communities where these have survived. The unusually high proportion of female headed units in many parts of the continent is also formally recognised. By the same token, however, there remains a tendency for researchers, government policy-makers and international advisors alike to adopt a static and undifferentiated approach to the household in SSA.
At the level of research relatively little attention has been devoted to: a) analysis of why and how household production units change in size, composition and form from month to month or year to year; b) the extent to which - and mechanisms by which - traditional household structures have been eroded and challenged by new family forms and social relations of production and reproduction; c) the complex variation in authority relations and power structures within household units. Yet all are crucial to analysis of production and women's activities in this sphere.

Many studies have pointed to the increased autonomy and room for manoeuvre women heads of households enjoy relative to those directed and supervised by male household heads in respect to the production process. Government officials and policy-makers are condemned for the gender-blindness inherent in their persistent neglect of women when it comes to rural development projects and extension services, targeted at 'rural producers'. Yet there is a marked tendency for analysts to fall back into the trap they are seeking to escape by treating all women as victims of male oppression within the household. Part of the problem stems from the failure to distinguish gender relations at the levels of household economic production unit, 
farming system and national political economy. This can result in female headed households appearing as a 'special case' when in reality they may be the opposite. One of the outstanding features of contemporary SSA is the fluidity and complexity of household forms.

Women's control over the decision-taking process within the household and their ability to meet and adapt to changing conditions tend to be shrouded in value-judgements deriving less from alien political perspectives than from alien socio-cultural and economic environments. The need to listen and respond to the needs and demands of 'peasants' most often of undistinguished gender - has been repeatedly stated [Chambers 1983:13]. There has on the whole been little concern with the demands of women rural producers, even by those committed to positive action. As a result the fact that there exist a significant number of women who, for example, seriously regret the demise of the polygamous household remains a mystery. The reasons for such preferences have rarely been taken seriously.

Finally, the concept of a female headed household requires definition. The broad distinction between de facto and de jure provides a starting point but requires clarification. De jure units are usually defined as those managed by women as a result of widowhood, desertion, divorce or the decision to remain single. The growth in these households, however, reveals a multiplicity of social forces at work. Of obvious importance is the breakdown in extended family structures and traditional social practices (e.g. inheritance of widows, arranged marriage) wrought by rapid socioeconomic change, increased inequality and impoverishment [Allison 1984]. Important also is the growth in women's autonomy in managing their lives independently of husbands and increased marital conflict resulting in divorce.

The vast majority of these households are, however, concentrated in urban centres or marginal rural areas because lack of independent access to land in most cases forces migration. More research is needed on how female headed households swelling the ranks of the rural poor and landless manage to survive in conditions where seasonal and casual employment is sharply reduced and market prices of food and basic necessitities are high [Allison 1985:20].

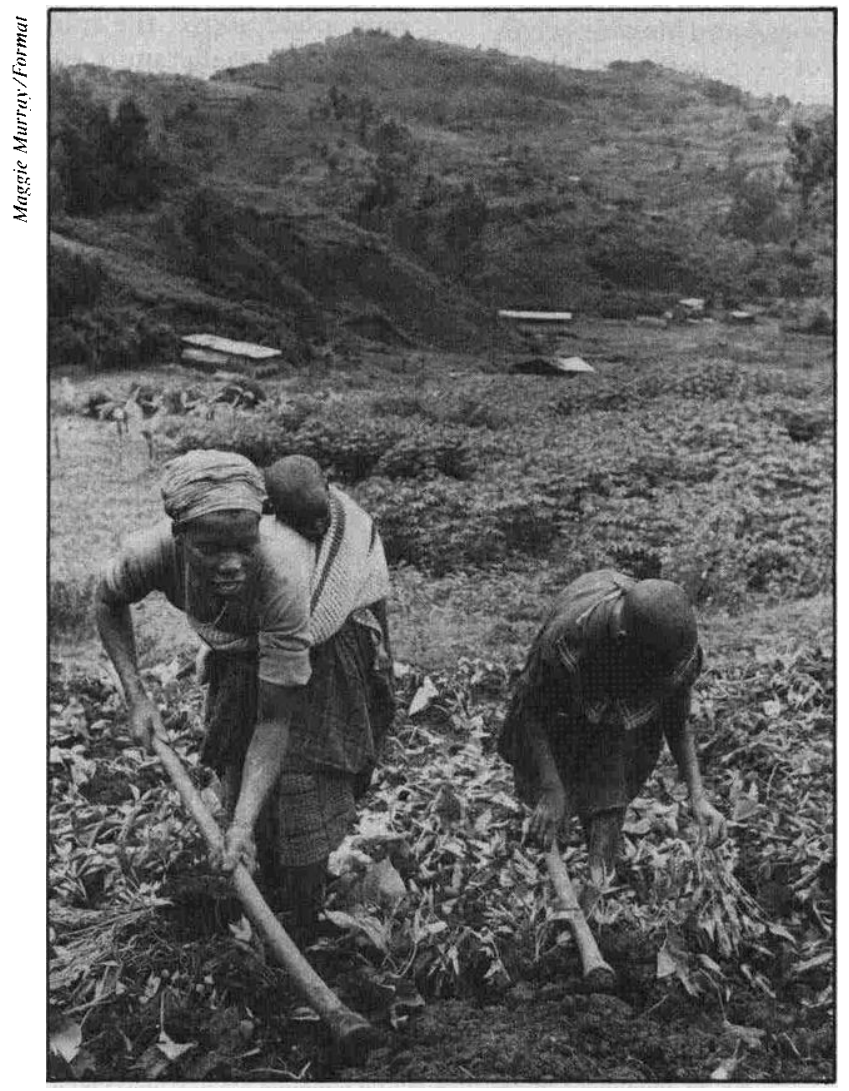

Women strive to maintain production single-handed. 
Within the rural sector there are in addition a growing number of de facto female headed units in which the male household head is absent for reasons most often associated with out-migration. In many cases a pattern has grown up in which men move on a semipermanent basis to urban centres, leaving their wives on the land to which they return during periods of ill health, unemployment or in old age. This nexus of relations is unlikely to be broken until land distribution patterns change and new forms of social security are found. The extent to which the women left behind control the production process and/or receive regular remittances is unclear, although there is every indication to suggest that they have become increasingly 'independent'. The degree of choice enjoyed in respect of crops and farming techniques is, however, largely contingent on the degree of contact between the absent husband-farmer wife. It is considerably reduced when the farmer returns to the farm on a weekly or fortnightly basis as, for example, appears to be the case in many parts of Zimbabwe.

Analysing the division of labour between men and women at the household level provides only a very partial view of patterns of labour use and allocation. It is clear that in households comprising a resident or actively involved absent male head and his wife/wives and children, women's control over their own labour and its products, particularly in respect of food production for household consumption is often greatly reduced. It is unclear as to whether this reality stems from traditional modes of male oppression, more modern forms of gender blindness or a combination of both. There is some evidence to suggest that although a fairly rigid division of labour and responsibility has always existed, it is the more recent alterations in resource and production patterns which have curtailed women's autunomy and reduced incentives. Payments made to male household heads on the sale of crops whether by state marketing boards or cooperatives have, for example, often bypassed women's traditional centrality in trading activities.

It is clear that research is needed on the gender division of labour at an intra-community level, as well as at a comparative intra-household level accounting for different household forms, in order to: a) challenge inappropriate western models of household units; b) highlight significant differences in patterns of production, labour allocation and farm management; c) reveal the mult if aceted networks of support existing between households which, if strengthened rather than challenged at a policy level, would have very positive implications both for rural productivity and poverty alleviation.

The amount of time and energy women spend on arduous chores such as water porterage, fuel collection and food processing is well documented. Analysis of deeper changes taking place at the level of the household and their implications for women's labour inputs and sources of income require evaluation, not least from the perspective of child welfare.

\section{Survival Strategies}

Throughout history women in SSA have set strategies in place on which they rely particularly in times of economic hardship and seasonal stress. Some of these, for example, changes in household food consumption patterns [Leakey 1985:3] have been carried over the ages, others have been evolved to meet specific, contemporary conditions.

Although famine rarely hits the headlines until it has entered a terminal phase, women's responses to its development are well illustrated by changes in food habits [Rangasami 1985:5]. As soon as food shortage develops they shift to gathering wherever possible foodstuffs reserved for periods of acute scarcity such as wild shrubs, berries and leaves. Over time foods normally considered to be toxic or poisonous are resorted to. Complementary strategies include, as mentioned above, the splintering of extended family forms into smaller units. Research conducted among a community of settled pastoralists in Mali, for example, reveals that when food is in relatively abundant supply extended family members grow, process, cook and eat food jointly, with - since these are defined as 'women's tasks' - positive implications for the diversification of productive and reproductive activities within the household and labour expenditure. In times of food scarcity nuclear units assume full responsibility for the members of their households [Swift et al. 1985]. This cycle relies in large part on seasonally determined economic factors such as market prices for grain and livestock, labour stress and unanticipated climatic shocks.

Other strategies include the long or shorter term migration of household members which serves to take the pressure off food supplies at the micro level, if not increase purchasing power and access to marketed foodstuffs. Reliance on child labour and the practice of sending children to relatives living in urban centres or better endowed rural areas also constitute an important safety valve, whether seasonal or more permanent.

In the early stages of a food crisis households tend to sell or barter anything from meagre grain stocks to small livestock and cattle, farm and household implements. Traditional ceremonies and festivities from marriage and initiation to funeral rites may be drastically cut back, the former being in most cases 
staged during months of the year when food supplies are expected to be greatest.

Child abandonment, infanticide, abortion and prostitution are also resorted to in times of imminent disaster, although all remain taboo subjects at the levels of research and state policy. Shunned as immoral, 'barbaric' or socially unacceptable, these strategies are often undertaken within the privacy of support systems women have established on pain of severe punishment if discovered by male members of the community.

In a context of rapid socioeconomic change, many of the survival strategies women traditionally adopted to ward off disaster have broken down. Land appropriation, deforestation and acute poverty, for example, have meant not only that access to wild famine foods has been restricted, but that trees and shrubs normally reserved for such purposes have been cut down and sold as firewood long before the terminal stage of food crisis has been reached. The breakdown of family systems has meant that women's ability to reduce the number of mouths to be fed through reliance on relatives has been curtailed. Rural development projects have in many cases uprooted families from communal support systems. Stringent rules and laws against practices such as infanticide and abortion may mean the premature death of other children in a family and increase the incidence of child abandonment.

Long before crisis develops, however, women respond rationally and persuasively to the circumstances in which they are placed. A much quoted example is that of Zambian women who, in the face of overt discrimination, responded to the government's exhortations to increase cash crop production by switching to vegetable growing and beer-brewing, or migrated to towns [Muntemba 1982:47]. The scale on which they have done this has prompted an investigation by the ECA and Ministry of Agriculture to find out what rural women need and want to improve their situation [UNECA 1981].

\section{Some Priorities}

In conclusion, five priorities for future work may be suggested:

a) research into different patterns of land distribution and use in SSA communities;

b) analysis of how rural development projects and changes in land distribution patterns have affected women's land use rights;

c) research to determine the nature and extent of rural landlessness among female headed households as a basis for policies to alleviate poverty; d) re-evaluation of SSA household forms, modes of inter and intra-household exchange, the status and problems of female heads of households with a view to strengthening existing support mechanisms and reducing stress;

e) research on traditional survival strategies and modern forms in SSA communities in the context of food crisis and recession as a basis for policy support prior to the terminal stage.

\section{References}

Ahooja-Patel, K., 1982, 'Another development with women', Development Dialogue, vols 1/2, pp 17-29

Allison, C., 1984, 'Reconstructing the family as the basic cell of socialist transformation', paper presented to the Annual Conference of the Development Studies Association, Bradford, September

- 1985, 'The impact of national adjustment on vulnerable groups in sub-Saharan Africa: towards an agenda of action to reduce the costs'. IDS, Sussex (mimeo)

Bisilliat, S. et al., 1985, 'Provisional synthesis document', International Workshop on Women's Role in Food SelfSufficiency and Food Strategies, Paris, January

Chambers, R., 1983, Rural Development: Putting the Last First, Longman, Harlow

Daniel, P., 1982, 'Employment, basic needs and poverty alleviation (issues and prospects in the current economic crisis)', Background Paper, Sixth Regional Conference, ILO Jobs and Skills Programme for Africa, Addis Ababa, February

Fortman, L., 1981, 'The plight of the invisible farmer: the effect of national agricultural policy on women in Africa', in R. Danber et al. (eds), Women and Technological Change in Developing Countries, Westview Press, Denver (Co), pp205-14

Jacobs, S., 1984, 'Women and land resettlement in Zimbabwe', Review of African Political Economy, No 27/28, pp $8-33$

Leakey, C., 1985, 'Biomass, man and seasonality in the Tropics', University of Cambridge, February (mimeo)

Lipton, M., 1984, 'Research and the design of a policy frame for agriculture', paper presented at OECD Development Centre/CERDI/IDS Conference on Rehabilitation and Recovery in SSA; forthcoming in Crisis and Recovery in sub-Saharan Africa: Realities and Complexities, OECD, Paris

Muntemba, S., 1982, 'Women as food producers and suppliers in the twentieth century: the case of Zambia', Development Dialogue, vols 1/2, pp29-51

Rangasami, A., 1985, 'Women's roles and strategies during food crises and famines'. International Workshop on 
Women's Role in Food Self-Sufficiency and Food Strategies, Paris, February

Savane, M., 1985, 'Femmes, production et crise alimentaire en Afrique au Sud du Sahara', International Workshop on Women's Role in Food Self-Sufficiency and Food Strategies, Paris, January

Swift, J., et al., 1984, Pastoral Development in Central Niger: Report of the Niger Range and Livestock Project, Niger

Times of Zambia, 1985, Report on UN Famine in Africa Conference, $17 \mathrm{March}$

UNECA, 1981, Information Kit for Women in Africa, Addis Ababa
UNICEF, 1984, The Impact of World Recession on Children. New York

Weekes-Vagliani, W., 1984, 'Women, food and rural development', paper presented at OECD Development Centre/CERDI/IDS Conference on Rehabilitation and Recovery in SSA; forthcoming in Crisis and Recovery in sub-Saharan Africa: Realities and Complexities, OECD, Paris

World Bank, 1981, Accelerated Development in sub-Saharan Africa: an Agenda for Action. Washington DC

-1984, Toward Sustained Development in sub-Saharan Africa, Washington DC 